\title{
A Theory of Hegemonic Stability in South American Regionalism? Evidence from the Case of Brazil in UNASUR and Venezuela in ALBA
}

\section{María Victoria Alvarez*}

\begin{abstract}
Both Brazil and Venezuela structured their foreign policy agendas in the early $21^{\text {st }}$ century on the projection of their respective leadership in regional schemes such as UNASUR and ALBA, respectively, following an intermediate hegemonic strategy. The loss of dynamism of these post-hegemonic initiatives problematizes the relationship between regional governance and the role of regional powers. ALBA is a scheme contingent on the political cycle and political voluntarism intrinsic in Venezuela's leadership. The bloc has lost members and relevance in recent years. As for UNASUR, most of its member states have withdrawn from the bloc and it is currently not operating. In short, post-hegemonic proposals lose dynamism and support once the leadership that promoted them weakens. A certain 'hegemonic stability theory' contextualized to South America with regard to the leadership of Brazil and Venezuela in recent years seems to be fulfilled: the decline in power of these countries helps to account for political reversals and changes in regional governance.
\end{abstract}

Keywords: South American regionalism; UNASUR; ALBA; intermediate hegemony; Brazil; Venezuela.

\section{Introduction}

During the long period of left-wing governments and the commodity boom (2003-2013) in Latin America, the academic debate focused on the characteristics, strengths and weaknesses of post-hegemonic regionalism as a response to the political withdrawal of the USA from the region. Regionalism may appear to lose momentum in the absence of US hegemonic force, but the uncertainties regarding the American grip were 'naturally fertile ground for a different traction and efforts to construct new legitimations' (Riggirozzi and Tussie 2012: 189). With visible Brazilian and Bolivarian Venezuelan leaderships, South America was where new frameworks of action redefined the visions and debates on

* National University of Rosario (UNR), Rosario, Argentina; maria.alvarez@fcpolit.unr.edu.ar. ORCID iD 0000-0002-2203-5082. 
integration and cooperation of the previous decade. In particular, this refers to the process that led to the creation of the Union of South American Nations (UNASUR, in Spanish) and the Bolivarian Alliance for the Peoples of Our America (ALBA, in Spanish).

UNASUR was formed in 2008, in continuity with the experience of the South American Community of Nations (CSN, in Spanish) launched by Brazilian President Fernando Henrique Cardoso, and composed by the 12 South American states, including Guyana and Suriname, traditionally linked to Caribbean regional initiatives. Venezuela and Cuba founded ALBA in 2004 as a scheme of assistance and South-South cooperation, with a strong anti-US ideological content (Briceño Ruiz 2014). With the inclusion of the program Petrocaribe, based on Venezuela's granting of oil subsidized prices and preferential payment options, ALBA reinforced its stance for a counterpoint with open regionalism.

With both Brazil and Venezuela facing heavy crises, UNASUR and ALBA are losing relevance and even disappearing. The analysis of the trajectory of these schemes consequently raises a number of interesting questions about the relationship between these countries' ambition to lead a regional project and the impact of the weakening of this determination. How does the leadership of regional powers relate to regionalism? But more importantly, and particularly, what happens to regionalism when regional leadership begins to decline? In order to answer this question, we rely on a double-case study. We analyse the phase of depolitization that UNASUR and ALBA are currently undergoing and ask ourselves whether (and to what extent) these developments relate to the decline of the headship of Brazil and Venezuela in the region.

The scope of this exploratory research was limited in terms of data collection. Based on a qualitative content-analysis of secondary sources, we provide the following hypothesis: post-hegemonic proposals lose dynamism and support once the regional leadership responsible for promoting them weaken. In this sense, some kind of 'hegemonic stability theory' contextualized to South America and the leadership of Brazil and Venezuela in recent years may be tested to assess if the decline of these leaderships contributes to account for the changes and political reversals in regional governance. Therefore, we aim at providing support for a regional version of hegemonic stability theory that may modify and even complicate some of the post-hegemonic regionalism scholarship. ${ }^{1}$

The paper is organized as follows. After this introduction, the next section proceeds in four steps to discuss some conceptual and theoretical dimensions around regional powers, hegemony, leadership, and post-hegemonic regionalism. The following two sections describe the role of two strong regional actors, Brazil and Venezuela, in structuring regional governance, in particular, UNASUR and ALBA. At the time of establishing these organisations, these two countries shared a significant domestic level change, including significant popular mobilization, strengthening of the state as the main actor in the economy, particularly through redistributive policies, and a decisive will to play a different role in regional governance, fending off external influence from the USA and the European Union (EU) (Riggirozzi 2012). The ensuing two sections depict the phase of depolitization that both UNASUR and ALBA are undergoing, in order to connect these developments with the 
decline of the regional leadership of Brazil and Venezuela as regional powers. Lastly, the conclusion presents some final considerations and suggestions for future research.

\section{Conceptual and theoretical considerations}

In order to address the key question posed in this article, this section proceeds in four steps. Firstly, it briefly discusses some notions of regionalism and regional power, adopting Detlef Nolte (2006) conceptualization. Then, a conceptual and theoretical discussion of hegemony and leadership follows, to contribute to the analysis of the role of Brazil and Venezuela in the regional governance landscape. In a third step, a short overview of the theory of hegemonic stability is cast, aiming to adapt its main elements to the context of $21^{\text {st }}$ century South American regionalism. The final step of this section is to assess the idea of a single dominant state articulating cooperation - in our case, a regional power - that could be somewhat at odds with post-hegemonic regionalism.

Due to practical constraints, this article cannot provide a comprehensive review of the vast literature on these issues. However, it is necessary to begin by clarifying some key terms. Regionalism refers to a general phenomenon that occurs all around the world today. It is linked to the need of a regional order, either in a given geographical area or as a type of world order. Regionalism, in this sense, is associated with a deliberate strategy, an intentional purpose, and can lead to the creation of formal institutions (Hettne and Söderbaum 2002: 34). ${ }^{2}$ Featuring regionalism as a deliberate process has important implications: there is an intentional strategy or a resolute willingness to build a regional space by an actor or actors, mainly states. The willingness of a particular state is so transcendental that it can be considered as one of the (supply-side) conditions for regionalism to develop (Mattli 1999).

A problem that arises in international relations (IR) literature is the surprising lack of attention given to disaggregating leadership into manageable component parts. Payne (1994) observes that scholars have all but failed to offer a description of the composition of hegemony beyond stating that it involves possessing an overabundance of power. As he notes, blunt suggestions of total dominance are not particularly useful when we turn our attention to the multifaceted and varied realms in which power can be exercised, especially when referring to emerging powers.

In that sense, it is possible to draw our attention to the contribution of Nolte (2006), who proposes an analytical concept of regional power. The author highlights the attributes of power and the possibilities of action for this type of state in a given geographical area. Here we focus on six attributes inherent to a regional power. Apart from expressing willingness of leadership in the region (willingness and role/perception) and possessing superior (military, economic, demographic, institutional and ideological) capabilities for a power projection in the region (resources), according to Nolte, regional leading powers are able to induce other states and actors inside and outside the region to accept their leadership (acceptance). Moreover, regional leaders influence the geopolitical delimitation and political-ideological construction of the region, which may marginalize certain 
countries (power of exclusion), practice the effective exercise of influence on regional matters (activities and results), and structure regional governance (Nolte 2006).

The capabilities and influence of a regional leader need to be placed within a broader context, in which systemic variables and domestic variables play a role as they complement any analysis of regional leadership. However, it cannot be denied that it would be wrong to assume that we can depict a single, fixed interpretation of what are complex and diverse drivers, given that influence on regional governance depends on a number of systemic factors that fall beyond the scope of this paper. Focus will hence be given to the domestic factors of the leadership of a regional power as explanatory elements of the swings of regionalism. ${ }^{3}$

Evidently, regional powers can adopt different strategies in regional politics (Destradi 2008). To account for this, expressions like hegemony and leadership are often used as synonyms in IR theory, even though their meanings and connotations are not similar. Analysing exhaustively the literature on leadership and hegemony in IR is beyond the scope of this paper, yet some of their fundamental features are presented.

Most of the academic literature focus on the global level (Destradi 2008), whereas the literature on the relationship between hegemony or regional leadership and regionalism is rather scarce (Nolte 2006). Only a few attempts to go beyond the global level and explore the regional realm have been made so far in IR theory (Pedersen 2002; Destradi 2008, 2010; Burges 2009; Poggio Teixeira 2011; Mourón and Onuki 2015; Ludwig and Sposito 2020). This strand of literature rests mainly on single-country studies (especially about Brazil in Latin America) and lacks wider empirical evidence.

Without delving too deeply into the conceptual debate on hegemony, we nevertheless have to be specific about what we mean by the term, and why and how we refer to it in the South American context of regionalism. The use of the concept of hegemony in association with the foreign policy of Brazil or Venezuela is a rather controversial issue (Alvarez 2020). At the root of this statement is an approach to hegemony that is especially visible in classical realist conceptions, and that practically equates it with imposition and adheres to a coercive perspective on the concept, which regards the struggle for power as a zero-sum game (Krasner 1976; Knorr 1975; Gilpin 1975). ${ }^{4}$

Rather than through a plain hegemonic strategy based on coercion, a region can be built based on consensus views and interests. The analysis of these issues consequently raises a number of interesting questions: 'Do regional leaders act in recognition of collective concerns, or as simply self-interest maximizers using the regional space as platform for achieving national and global interest?' (Riggirozzi and Tussie 2012: 4).

According to the goals pursued and to the means employed by the dominant state, a distinction between hegemony and leadership (and a division of hegemony into subtypes) is enabled (Destradi 2008, 2010). The commonality or divergence in the goals pursued by the regional power and neighbouring countries highlight the fact that the hegemon primarily follows its own interests. In contrast to the 'one-sidedness' of hegemony, the prominent feature of leadership is the pursuit of common interests and goals.

From this perspective, leaders and followers join based on a functional definition of the common beneficial to all parties, even after hegemony, despite it, or even beyond it 
(Keohane 1984). As stated by Ikenberry (2001: 28), the order is still organized around asymmetrical relations but the coercive aspects of it are 'muted.'

With regard to the means employed by a regional power in its relations with other countries, the notion of intermediate hegemony proves useful. Intermediate hegemony focuses on the fact that 'norms and values are shared to a certain degree between hegemon and subordinate states' (Destradi 2008: 16), in which case the hegemon pursues its narrow national interest and its own goals, but emphasizes the existence of common interests and objectives that are shared with subordinates. The side payments provided by the intermediate hegemonic state are mainly of an economic nature, and the compliance of subordinate states derives from rational cost-benefit calculations (Destradi 2008).

The important point we wish to make is that a considerable degree of regional building in South America in the $21^{\text {st }}$ century may be compatible with this concept of hegemony. Intermediate hegemony is centred on the provision of material benefits and rewards to subordinate states (as suggested by hegemonic stability theory) in order to make them acquiescent. The existence, to a certain degree, of common values and the absence of threats make the intermediate hegemonic strategy more acceptable for subordinate states than the hard strategy (Destradi 2008). In this usage, it refers to 'a form of power situated at an intermediate level' between outright imperial domination and more benign notions of 'leadership' (Cox 1981; Destradi 2010: 912). This form of hegemony 'also inheres in ideas, norms, and discourse' (Kennedy and Beaton 2016: 63).

Since we are interested in explaining whether regional schemes may fade or stagnate when regional hegemonic leadership declines, a brief discussion around the theory of hegemonic stability is needed. Without taking the specificities of its international historical circumstances into consideration, some of its key elements may still provide a useful frame of reference for analysis. Thus, the theory of hegemonic stability remains a powerful realist theory about international co-operation (Pedersen 2002), emphasizing the provision of public goods in the international economy and focusing on the role of material incentives.

A state following an intermediate strategy might also secure joint benefits with its subordinates. As the theory of hegemonic stability tells us, subordinate states take advantage of the collective goods provided by the hegemon - and gain even more than the hegemon itself, given that they act as free riders. However, this does not necessarily mean that they willingly follow the leader in its effort to reach common goals.

In the case of South America, as Riggirozzi and Tussie (2012) assert, infrastructure, security and monetary policy were areas that shifted control from the dominion of the USA and from US-supported institutions to new institutions and arrangements where Brazil has been a key articulator. Likewise, thanks to high oil prices, Venezuela's determination for a transnational economic conception of welfare provided a new set of incentives away from strictly market-based ones.

In accordance with the theory of hegemonic stability, which in basic terms, predicts the instability of institutional schemes once leadership begins to decay, we may assume that regional governance is affected when leadership declines. Thus, we may argue that the decline of Brazil and Venezuela's intermediate hegemony laid the ground for the weakening of both UNASUR and ALBA and for the discontinuation of cooperation within these schemes. 
Whereas the concept of intermediate hegemony focuses on material forces, it would also underscore the power of ideas. These arguments are also valuable indicators of the declining phase of hegemony. Here, what matters is not only the economic decline of Brazil and Venezuela, but also the failure of their governing ideologies to provide regional stability and improved outcomes.

Post-hegemonic regionalism hinges on an understanding of hegemony that goes beyond material domination. In this vein, other than hegemonic politics, regions can be constructed based on consensual views and interests that, although advanced and guaranteed by the leader, reflect the position of the followers (Riggirozzi and Tussie 2012).

In this case, we will not follow Briceño-Ruiz (2018: 574), who argues that post-hegemonic regionalism means 'the absence of any kind of hegemony.' In fact, we argue that hegemonic actors other than the USA may exert influence on shaping the regional order. Post-hegemonic structures were characterized by 'hybrid practices as a result of a partial displacement of dominant forms of US-led neoliberal governance in the acknowledgement of other political forms of organization and economic management of regional (common) goods' (Riggirozzi and Tussie 2012: 12).

\section{Brazil as a regional power and regionalism}

Brazil directed its foreign policy towards the region and promoted an initiative such as the Southern Common Market (MERCOSUR, in Spanish) in the early 1990s. However, the promotion of regionalism had a leading place on the Brazilian foreign policy agenda in the post-Cold War period, especially during the administration of President Lula da Silva (2003-2011). The starting point for this analysis assumes that Brazil was a regional power in the early $21^{\text {st }}$ century and that its central strategy to advance leadership was 'the creation of regional schemes' (Burges 2009: 11).

However, there is an active debate among academics over Brazil's role in South America (Mourón and Onuki 2015). As Caetano, López Burian and Luján claim (2019: 195), Brazil's leadership - or purported leadership - on the South American region is a matter that generates dissent in the specialized literature. While a group of academics confirms the existence of Brazil's regional leadership, others question its capabilities to in effect build such strategy. We could add a third group, made up of authors who suggest that Brazil had the capabilities to exercise South American leadership, which was nonetheless objected to by other countries, and therefore, was not consolidated (Mourón and Onuki 2015: 11).

Brazilian diplomacy assumed the role of regional leader and steered its behaviour towards the formation of consensus between different visions. In the year 2000, President Cardoso organized a first meeting with the region's governments, with the formation of a South American community in mind. By limiting the initiative to South America, Brazil tacitly recognized the limitations of its influence in the rest of Latin America and accepted divergences in economic interests in the region (Quiliconi and Salgado Espinoza 2017). 
This initiative led to the creation of the CSN in 2004, which subsequently evolved into UNASUR with a strong cooperative bias, an expanded agenda, and an intergovernmental and low level institutional structure. UNASUR then emerged in an extremely favourable regional context to promote regionalism. Brazil rose as an emerging power and the foreign policy led by Lula placed South America as a priority area for the country's global insertion (Burges 2009: 185).

Unlike other regional experiments, UNASUR did not emphasize economic and trade integration, but was rather consolidated as an organization where agreements on political, security and defence issues prevailed. Brazilian diplomacy worked with a view to building a consensus among neighbouring countries within UNASUR in the face of difficult situations, and always seeking 'to occupy a prominent role' (Gomes Saraiva 2012: 98).

If we apply Nolte's analytical framework (2006), to a greater or lesser extent, Brazil met most of the requirements to be a regional power (Table 1). The political-ideological construction of the region, from the Brazilian perspective, naturally included all South American countries, but involved designing a geopolitical space excluding all those countries North of Colombia's Northern border, in particular Mexico, and also gaining autonomy vis-à-vis the USA, constituting the power of exclusion characteristic.

Table 1 - Characteristics of a regional power

\begin{tabular}{lccc}
\hline Regional Power Characteristics & Brazil & Venezuela \\
\hline Willingness and role/perception & $?$ & $\checkmark$ \\
\hline Power of exclusion & $\checkmark$ & $\checkmark$ \\
\hline Acceptance & $?$ & $\checkmark$ \\
\hline Resources & $\checkmark$ & $\checkmark$ \\
\hline$\quad$ Material resources & $\checkmark$ & $?$ \\
\hline$\quad$ Ideational resources & $?$ & $\checkmark$ \\
\hline Activities and results & $\checkmark$ & $\checkmark$ \\
\hline Structuration regional governance & $\checkmark$ & $\checkmark$ \\
\hline
\end{tabular}

Sufficient $\checkmark$ - Insufficient $X$ - Fluctuant?

Source: Created by the author based on Nolte (2006).

By explicitly articulating the concept of a South America as a distinct regional subsystem, Brazilian administrations recovered a recurrent topic of Brazil's foreign policy:

In contrast to the rest of Latin America, where Brazil would seek not to get involved and would - sometimes tacitly, sometimes explicitly - recognize US pre-eminence, South America was understood by Brazilian policy makers as being a Brazilian sphere of influence where US interference should be kept at arm's length (Poggio Teixeira 2011: 204). 
As for the willingness and perception that Brazil had about the claim of leadership in the region, as explained above, the case is complex. As Burges (2009: 183) elucidates, 'where Cardoso was quiet about Brazilian ambitions to leadership, Lula was explicit, seeking overtly to deploy the currency of ideas as a device for leading a resurgent globally-oriented Southern movement.' Lately, Dilma, and more emphatically, Temer and Bolsonaro, have degraded the role of Brazil in the region due to changes in foreign policy's priorities, as well as limitation of resources.

The recognition of Brazilian leadership by other countries in the region and outside of it, the so-called acceptance (Nolte 2006), is only partially fulfilled in the case of Brazilian leadership. Some experts argue that Brazil was 'a leader without followers', because while it promoted the global integration of South America as a unified bloc, the rest of the countries in the region did not fully sacrifice their own foreign policy agendas (Malamud 2011). Others argue that, for a short time, when most South American countries were in the hands of leftist governments, it was possible for them to partially align their international agendas around the UNASUR project, precise period in which the scheme had its best prospects (Flemes and Wojczewski 2010).

UNASUR allowed Brazil to implement two basic regional power leadership premises: the effective exercise of significant influence on regional issues - namely, activities and outcomes - along with the possibility of doing so through governance structures, that is, by structuring regional governance. Brazil expanded its sphere of influence from MERCOSUR to UNASUR and even to the Community of Latin American and Caribbean States (CELAC, in Spanish), regarding regionalism as a step in the building of its regional leadership (Quiliconi and Salgado Espinoza 2017).

With regard to material resources for a projection of power in the region, in absolute and relative terms, Brazil is undoubtedly the most powerful country in the region (Mourón and Onuki 2015: 10-11). Brazil dominates the South American landmass and shares land borders with every South American country excepting Ecuador and Chile. As indicated by Table 2, Brazil's total population is much larger than that of the rest of the South American countries combined. Comparisons of GDP indicators are also in its favour. Brazilian GDP in the last ten years has been larger than the GDP of all remaining South American countries collectively. Therefore, Brazil's sheer size - in terms of geography, demography and economics - ensures its primacy in the region.

The provision of material incentives or side payments is relevant for understanding intermediate hegemony. In the case of Brazil, the National Bank for Economic and Social Development (BNDES, in Portuguese) began to lend money for infrastructure projects in other South American countries conducted by Brazilian companies (Gomes Saraiva 2010). BNDES provided funding to the South American Regional Infrastructure Integration Initiative (IIRSA/COSIPLAN, in Spanish) aiming to develop a regional infrastructure (Gomes Saraiva 2012). ${ }^{5}$

BNDES was a key IIRSA/COSIPLAN funder and made massive loans to Brazilian construction firms for international projects, under the figure of export of goods and services. As Ludwig and Sposito (2020: 186) assessed, 'The large projects developed within 
the scope of IIRSA would make the internationalization of Brazilian private oligopolies feasible, which came to dominate a significant part of the domestic markets of its neighbours, consolidating the economic aspect of the Brazilian projection in hegemonic terms.'

Table 2 - Geographic, Demographic and GDP Indicators of South American Countries

\begin{tabular}{lccccc}
\hline Country* & $\begin{array}{c}\text { Area } \\
\left(\mathbf{k m} \mathbf{2}^{\mathbf{2}}\right.\end{array}$ & $\begin{array}{c}\text { Total } \\
\text { Population } \\
\text { (in millions, } \\
\mathbf{2 0 0 5} \text { est.) }\end{array}$ & $\begin{array}{c}\text { Total } \\
\text { Population } \\
\text { (in millions, } \\
\mathbf{2 0 1 9} \text { est.) }\end{array}$ & $\begin{array}{c}\text { GDP } \\
\text { (2005 in } \\
\text { millions, } \\
\text { US\$, 2010) }\end{array}$ & $\begin{array}{c}\text { GDP } \\
\text { (2017 in } \\
\text { millions, } \\
\text { US\$, 2010) }\end{array}$ \\
\hline Brazil & $8,511,965$ & 186.13 & 211.05 & 891,634 & $2,055,512$ \\
\hline Venezuela & 916,445 & 26.43 & 28.52 & 145,514 & 255,093 \\
\hline Argentina & $2,780,400$ & 38.89 & 44.78 & 200,622 & 637,486 \\
\hline Bolivia & $1,098,581$ & 9.23 & 11.51 & 9,549 & 37,509 \\
\hline Chile & 756,626 & 16.18 & 18.95 & 122,965 & 277,081 \\
\hline Colombia & $1,141,748$ & 42.65 & 50.34 & 146,566 & 309,191 \\
\hline Ecuador & 283,560 & 13.83 & 17.37 & 41,507 & 104,296 \\
\hline Paraguay & 406,752 & 5.82 & 7.04 & 8,735 & 29,435 \\
\hline Peru & $1,285,216$ & 27.87 & 32.51 & 76,080 & 211,403 \\
\hline Uruguay & 177,414 & 3.32 & 3.46 & 17,363 & 59,180 \\
\hline
\end{tabular}

Brazil's performance in this area, however, persisted with tensions. On the one hand, the requirement for the country to fulfil the financial role of the paymaster was strong ${ }^{7}$; on the other, the Brazilian government had to struggle in order to obtain internal political support for its regional leadership project and for its intentions to take on some of the costs of South American regionalism (Gomes Saraiva 2010). In the Brazilian case, the unwillingness to impose was accompanied by an inability to absorb the costs associated with imposition (Burges 2009). As Burges (2009: 188) emphasizes, 'Brazil was unable to truly take on the costs of leadership and fulfil the role of economic engine for South America.'

Yet, Brazilian tolerance of some actions contrary to its interests, even in light of paying high domestic costs, implies that the country did not penalize its potential followers. The nationalization of the hydrocarbons sector carried out by the Bolivian government in 2006 -which directly affected the interests of the Brazilian state-owned Petrobras - and the expulsion of the company Odebrecht from Ecuador in 2008 are examples thereof. In these cases, the Brazilian government opted to lower the levels of confrontation and yield to the demands of its neighbours (Mourón and Onuki 2015).

Our approach assumes that material power factors and ideational aspects interact in the exercise of intermediate hegemony. Regarding ideational resources, Brazilian ideas were certainly not rejected by the other South American countries, yet neither were they wholeheartedly embraced. The suggestion that national development might be best pursued through collective action via the creation of a region was viewed with some interest, 
but not to the extent that 'other states on the continent absorbed the substance of the project and unconsciously used it as the basis for the independent formulation of new policies' (Burges 2009: 187). Brazil has highlighted the strategy of pushing common responses based on discussion and inclusion as one of its strengths. In particular, in IIRSA/ COSIPLAN and UNASUR, 'the Brazilian foreign ministry has articulated a pluralistic agenda and has led a discourse of consensus creation in South America' (Flemes and Wojczewski 2010: 13).

Acknowledging leadership as being characterized by a commonality of interests between leader and followers, and hegemony as essentially self-interested and aiming primarily 'at the realization of the hegemon's goals, which, however, are presented to subordinate states as collective goals' (Destradi 2008: 14) allows to arrive at accurate judgements. Malamud (2011) asserts that the lack of support from South American countries for Brazilian candidacies in international organizations - such as the World Trade Organization (WTO) and the Inter-American Development Bank (IDB) - as well as for the Brazilian initiative to secure a permanent seat in the UN Security Council, were all signs of the Brazilian inability to be a leader. Nonetheless, those were not regional common objectives, but in turn Brazilian goals. This was an indication that Brazil was not conducting a leadership exercise but a hegemonic (though intermediate) one instead.

In short, while potential supporters have been wary and there have been tensions, there has never been a frontal rejection of Brazilian leadership as such (Mourón and Onuki 2015). The intention was not to seek Brazilian leadership through imposition, but to foster a beneficial order that would boost its interests, aspirations and strategies in the region. Broadly speaking, Brazil fulfilled the role of an intermediate hegemon. However, as Pedersen (1999, cited in Destradi 2010: 919) underlines, the side payments provided by Brazil were not mainly of economic nature but rather took the form of institutional power sharing, especially in UNASUR. ${ }^{8}$

\section{Venezuela as a regional power and regionalism}

ALBA began as a partnership between Hugo Chávez's Venezuela and Fidel Castro’s Cuba, ${ }^{9}$ which was later joined by other countries. It represented an unprecedented attempt of Latin American regionalism to promote an agenda not solely based on trade liberalization, but on cooperation, the exchange of human resources, and solidarity (Serbin 2007, cited in Riggirozzi 2012: 140).

Even though the regional base of Venezuela's leadership was ambiguous, ${ }^{10}$ President Hugo Chávez managed to position the country in the epicentre between Central America, South America and the Caribbean. ${ }^{11}$ Moreover, Venezuela played a pivotal role in the region's integration dynamics (Flemes and Wojczewski 2010) and is often regarded as a major player and decisive actor for the creation of regional institutions in South America. ${ }^{12}$

ALBA quickly proved to be an instrument for building alliances according to Chávez's interests, looking for ways 'to consolidate Venezuelan leadership in the region' (Dabène 2009: 211). In April 2006, Bolivia decided to join the scheme and along with Cuba and 
Venezuela, signed a Treaty on the Cooperation of Peoples (TCP, in Spanish). ${ }^{13}$ Nicaragua joined in 2007, although Nicaragua had already ratified the Dominican Republic-Central America Free Trade Agreement with the USA (DR-CAFTA). In January 2008, the Caribbean island of Dominica joined. Chávez failed to gather much more support, with the exception of Ecuador, a member since June 2009, and some small Caribbean countries.

Clearly, Venezuela possessed most of the attributes of a regional power (Table 1). Caracas held the ideological resources for a projection of power in the region. Furthermore, since 2003, the country enjoyed a significant flow of economic resources to finance its international strategy. Venezuela's regional integration moves were coupled with a generous redistributive policy, including the Petrocaribe initiative born in 2005, initially with fourteen partners. ${ }^{14}$ The initiative was able to reach eighteen members, namely Central American and Caribbean nations, in addition to Venezuela (López Canellas and Villani 2014: 187). ${ }^{15}$

Its financial capacity provided Venezuela with economic capabilities that allowed the country to develop through ALBA a soft balancing against the USA (Briceño Ruiz 2014). ALBA emerged as a way to counteract the US goal of creating the Free Trade Area of the Americas (FTAA), and then proposed an integration model that rejected the Free Trade Agreements (FTAs) model that Washington aimed to expand in the region.

Although Venezuela was not part of a well-demarcated region either geographically or economically, the country did exert a strong influence on geopolitical delimitations and on a political-ideological construction to marginalize the USA (power of exclusion), leading the opposition to the FTAA initiative since the 2001 Quebec Summit, and whose climax took place at the 2005 Mar del Plata Summit.

According to some experts, the ability to exclude countries also involved Brazil. In that sense, some argue that ALBA was born 'as a mechanism to balance Brazil's growing influence in South America' (Briceño Ruiz 2012: 143-144), although it is possible to claim that the Bolivarian bloc was trying to drive a certain balance vis-à-vis Brazil, whereas not necessarily a competition (Briceño Ruiz 2012).

Venezuela intended to acquire some degree of leadership in the region (willingness and role/perception). The promotion of the Latin American regionalism was conceived in both economic, social and political terms. Both ALBA and Petrocaribe were part of the actions of the Venezuelan foreign policy established during the presidencies of Chávez, whose political conception was interpreted as a strategy of projecting the Venezuelan preponderance at the regional level (López Canellas and Villani 2014).

The Venezuelan leadership was recognized - or at least respected - by other countries in the region (acceptance). The countries that accepted Venezuelan aid also adopted its agenda on regionalism. Venezuela fully understood that for a medium power to be accepted as a regional leader, it had to provide significant benefits to smaller countries.

The strategy worked due to the fact that the possibility of obtaining oil under special conditions - especially in an international context of high prices, in addition to obtaining loans and aid without any conditionality, was an offer some countries in the region simply could not reject. Venezuela managed to strengthen ALBA as a bloc with its own 
voice in the regional and global scenarios and 'as a model of counter-hegemonic integration' (Briceño Ruiz 2014: 172). ALBA developed a strategy that abandoned the region's 1990s neoliberal policies. Chávez's foreign policy objectives highlighted 'the need to promote a model of political integration that overcomes the injustices of globalization and its devastating neoliberal strategies' (Blanco and Linares 2008 as cited in López Canellas and Villani 2014: 182). Subsequently, ALBA began to be described as an anti-imperialist bloc, which was a milestone in the post-hegemonic stage of South American regionalism (Riggirozzi and Tussie 2012). ${ }^{16}$

Venezuela effectively exerted great impact on regional affairs (activities and outcomes), both in ALBA and in Petrocaribe's areas of influence. According to the official TV network, ALBA's greatest achievements include more than 2,800,000 citizens that regained the vision through Operation Miracle; the eradication of illiteracy in Venezuela, Bolivia and Nicaragua; more than 12,000 member countries' doctors trained in Cuba and Venezuela; and more than four million people who successfully benefited from the adult literacy Cuban method 'I can' (Telesur 2018). Petrocaribe's cooperation flows, meanwhile, reached values similar to the total gross Official Development Assistance (ODA) granted by some donor countries. ${ }^{17}$ These figures show Petrocaribe's relevance as an instrument of South-South cooperation (López Canellas and Villani 2014: 196).

Venezuela exerted a clear influence through regional governance structures (structuring regional governance), not only through ALBA and Petrocaribe, but also thanks to CELAC and UNASUR. The country repeatedly insisted on strengthening the institutionalization of CELAC, especially vis-à-vis the Organization of American States (OAS); this was regarded as 'a mechanism of domination of US foreign policy' (Kennedy and Beaton 2016: 66-67).

As for UNASUR, Caracas perceived it as an opportunity to carry out its own strategies towards South America and promote the Bolivarian project of regionalism. ALBA was a relevant force within UNASUR and Chávez's softened proposals found their way into the organisation's decision-making process. In particular, Brazil was the country that 'regionalized' and 'South Americanized' Venezuelan proposals (Sanahuja 2012: 49). Brazil, revealing intermediate hegemonic strategies, was able 'to incorporate the interests of other South American countries into UNASUR's agenda' - even if it responded to the geopolitical design of that country (Sanahuja 2016: 44). In its quest to structure regional governance, Venezuela also withdrew from the Andean Community of Nations and joined the MERCOSUR.

In short, Venezuela enjoyed most of the dimensions of a regional power in the period under analysis. Its resources from the oil revenue and the use of ideological and anti-American rhetoric provided Caracas with a group of followers among small countries in Central America and the Caribbean. In South America, its influence was felt in regional structures led by other regional powers such as Brazil. Venezuela was able to perform a strategy close to intermediate hegemony focusing on the provision of material incentives, and additionally, privileging the role of ideas in the establishment of regional hegemony (Destradi 2010). In the Venezuelan case, ideational and material power resources were always operating together and influencing each other. 


\section{The 'decline' of Brazil's regional leadership and its implications for regionalism}

In UNASUR, a process of depolitization was initiated due to the decisions of more than half the governments that left the organization. As early as April 2018, the government of Brazil along with Argentina, Chile, Colombia, Paraguay and Peru decided to temporarily suspend their membership. The Colombian government withdrew from the bloc afterwards. It was followed by the government of Ecuador in March 2019, Argentina, Brazil and Paraguay in April, and of Chile in June. In May, the government of Peru submitted to Congress the denunciation of the UNASUR Treaty. Moreover, Ecuador evicted UNASUR from its headquarters in Quito. Uruguay also left UNASUR after Lacalle Pou's triumph in presidential elections. Additionally, after the abrupt departure of Evo Morales from Bolivia, the interim government also planned to leave the bloc.

Currently, UNASUR is composed only of Bolivia, Guyana, Suriname and Venezuela. The collapse of this body, unthinkable ten years ago in many circles that promoted its institutionalization, seems inevitable. However, in a traditional dynamic of Latin American regionalism, the disappearance of UNASUR was masqueraded with the creation of a new initiative called Forum for the Progress and Development of South America (PROSUR, in Spanish).

We may use our conceptual framework to analyse the waning of Brazil's hegemonic leadership and how this was reflected on regional institutional bodies such as UNASUR. In recent years, Brazil has plunged into successive political, economic and institutional crises. The domestic factor, in this sense, has played a key role in weakening the Brazilian leadership in the region. According to a recent study (Caetano, López Burian and Luján 2019), a majority of scholars point to the political crisis that the country has experienced as a consequence of the removal of President Dilma Rousseff as an influential or very influential factor in the decline of Brazil's direction over the South American region. The second factor identified relates to the impact of the Brazilian economic crisis.

It is precisely the dimension of commitment to leadership in the region (willingness and role/perception) which has recently faded in Brazil. The country's commitment as a regional leader began to decline during the government of Dilma Rousseff (2011-2016) not because it has not previously been controversial, but because doubts about the importance of Brazil's involvement in regional governance increased. With the implosion of an enormous scandal, the so-called Operação Lava Jato or Operation Car Wash, which ended with the impeachment to Rousseff and a consequent crisis, there was an abandonment of the postulates of post-regionalism and the return to the axes of open liberalism (Pereyra Doval 2019).

Conversely, Rousseff's presidency coincided with a worsening of the economic situation, political mismanagement, and a more introverted foreign policy. This combination of internal crisis and less external projection meant a clear decline of Brazil as an international and regional player. The shift experienced in 2016 by the Temer administration adopted a clear liberal-conservative orientation, downgrading regionalism as a non-priority in the context of a changing international stage. 
Temer's administration suspended Brazil's membership in UNASUR at the same time Macri did so in Argentina, Piñera in Chile, and Duque in Colombia. The convergence of ideological signs among South American governments ceased to occur in centre-left terms, and moved to centre-right and right orientations. Bolsonaro has shown no interest in the region; ${ }^{18}$ however, his administration remains active in informal mechanisms of South American concertation such as PROSUR (Pereyra Doval 2019).

\section{The 'decline' of Venezuela's regional leadership and its impact on regionalism}

By 2012, at the zenith of ALBA, there were already doubts about Venezuela's consensus-building capabilities for a viable regional project, due to its strong ideological orientation. In addition, the project was difficult to be sustained based on Venezuelan alliances and resources, in particular with regard to the possibility of extending the oil revenue model to the whole region (Serbin 2011).

Traditionally, Venezuela had been South America's oil biggest producer. Its oil reserves, that account for $18 \%$ of the world's total oil production, overtake those of Saudi Arabia. However, the past decade's political and economic instability has taken its toll on production. Venezuela's crude oil production has declined rapidly and fallen to a 20year low since $1997^{19}$ (Energy Information Administration [USA] 2019). ${ }^{20}$ Moreover, Venezuela's revenue from oil exports is severely constricted because only about half of the exports generate cash revenues ${ }^{21}$ (Energy Information Administration [USA] 2019).

Especially since President Chávez's death in March 2013, there has been no clear leadership in ALBA. The integration model worked for a while, but it had a serious weakness: its financial dependence on Venezuela. The country constituted the paymaster that allowed the ALBA model to work for a few years and, in Petrocaribe, delivered the oil under special conditions (Briceño Ruiz 2014).

Chávez's death announced 'the beginning of the end' of the brief period of Bolivarian leadership in the region. ALBA significantly lost members and may continue to lose additional members in years to come. On the one hand, the Ecuadorian government announced its withdrawal from ALBA ten years after its accession, as a result of the migration crisis. More recently, the Bolivian interim government broke off diplomatic relations with the government of President Maduro and announced its withdrawal from ALBA. A day before the Bolivian announcement, ALBA's Political Council refused to recognize the new government of Bolivia. ALBA is now composed of only two countries in the continent (Venezuela and Nicaragua) in addition to insular Caribbean countries (Antigua and Barbuda, Cuba, Dominica, St. Lucia, St. Vincent and the Grenadines, Grenada and St. Kitts and Nevis).

Meanwhile, Guatemala withdrew from Petrocaribe in 2014 and Belize in 2017, due to the sharp fall in Venezuela's oil production, which did not allow the agreements to be practically implemented. Finally, in June 2018, Venezuela announced the suspension of its shipments to Antigua and Barbuda, Dominica, El Salvador ${ }^{22}$, Nicaragua, St. Vincent 
and the Grenadines, St. Kitts and Nevis and Haiti (Antonin 2018). As for the results of this initiative, there have been no significant improvements for the societies involved, and in many cases - as Haiti tragically demonstrated - has financed government corruption (Antonin 2018).

Clearly, the strategic policy of alliances depended on the economic swings of postChavist Venezuela. The breakdown of the Venezuelan economy is being decisive in this relative failure because it narrows the chances oil being used for foreign policy actions. However, it is difficult to know the actual status of these processes, since initiatives such as ALBA or Petrocaribe do not embody integration in classical terms and lack institutional mechanisms to follow up on their vision.

According to our conceptual framework, resources represent the most resentful dimension of Venezuelan leadership in recent years, not concerning discursive or ideological resources, but rather those more tangible linked to oil revenues and their potential to gather consensus and willingness around a common project.

A few years ago, Serbin (2012: 107) claimed that ALBA qualified to be part of a regionalism that aspired to be post-hegemonic only if it achieved a more structured institutionality and sustainability independence from international oil prices and domestic policy vicissitudes in Venezuela.' ALBA failed to be independent of these factors because it was never really prepared to do so. In parallel, with the decline in Venezuela's oil revenues and in light of Venezuela's political, economic and institutional collapse, the scheme weakened, and is falling apart, as well as Petrocaribe.

One of ALBA's major weaknesses has always been its dependence on Venezuelan funding, that has progressively vanished. As a result, even though the anti-US and pro-social issues rhetoric is being maintained, its ability to promote a radical post-hegemonic model has declined (Briceño Ruiz 2018). Without side payments available to followers, Venezuelan intermediate hegemony loses momentum since the anti-US narrative does not compensate for the economic collapse of the country's economy.

\section{Conclusions}

In the early years of the $21^{\text {st }}$ century, two outstanding regional leaders with distinct capacities emerged in South America. As stated above, two essential factors help discriminate between hegemony and leadership: the commonality or divergence in the goals pursued by the regional power and neighbouring countries, and the means employed by the regional power (Destradi 2010). We have characterized Brazilian and Venezuelan strategies as intermediate hegemonic strategies grounded on different kinds of incentives and side payments, whose goals were not always based on commonality.

Despite increasing scholarly interest in regional powers, few attempts have been made to go beyond the explanation of these states' strategies during the life spam of any regional endeavour in order to identify the process regionalism undergoes when regional powers decline. This paper aimed to contribute to this particular debate by developing a broader conceptualisation of the hegemonic stability theory and by identifying the main features for South American regionalism, specifically concerning Brazil and Venezuela. 
Venezuela stood out thanks to oil cooperation (Lorenzini and Ceppi 2013) and regional initiatives such as ALBA. Meanwhile, Brazil was the main sponsor of the CSN and of its direct successor, UNASUR. Nonetheless, the impetus of these two countries has vanished in recent years. Venezuela is immersed in a deep economic, political and social crisis, albeit struggling to maintain its ideological discourse and ideational projection. Meanwhile, Brazil has turned to the right and seeks to open up amidst strong swings in its political, economic and institutional situation towards a growing interlocution with China, the EU and the US - although this process may also be a contradictory one.

Brazilian diplomacy led the way in regional schemes of cooperation and increased the level of infrastructure investment in neighbouring countries, sending signs that Brazil was willing to exercise effective leadership in South America (Mourón and Onuki 2015). For some analysts, having been able to endorse institutions such as UNASUR, Brazil played an important role in promoting regional governance, displaying an ability to bring about consensus among countries with different economic and external policies.

For some years now, we have been hearing that Brazil's leadership was not a matter of choice. Given the size of its territory and economy, Brazil was 'condemned' to play a leadership role. However, in a less satisfactory context than the decade that preceded it, Rousseff's government struggled to maintain the responsibilities of the growing Brazilian leadership. These drawbacks coupled with Dilma's impeachment and the emergence of a liberal-conservative government, changed foreign policy priorities, and weakened leadership pretensions in the region. In Nolte's terms (2006), it was the willingness element that was left aside in the Brazilian case, along with a limitation of material resources.

Despite some important accomplishments in its early years, UNASUR quickly stagnated without Brazil's meaningful leadership. As of 2020, the organization has become an empty shell, a victim of a lack of strong political commitment. Currently, regional guidance is not a priority for Bolsonaro's presidency, and its foreign policy is structured in antithetical terms in contrast to former administrations. Bolsonaro avoids closer relations with neighbouring countries in pursuit of a 'de-Americanization' of the Brazilian foreign policy agenda, proposing to distance Brazil from the region (Frenkel 2018).

ALBA is a scheme conditioned by its low institutionalization and its marked ideological profile. So long as oil prices were benefiting Venezuela, ALBA likewise benefited. Yet, when the Venezuelan economy collapsed, also due to the fall of oil prices, ALBA suffered the consequences thereof, revealing that the functioning of the organisation was contingent to Venezuelan domestic politics (Serbin 2011). In the case of ALBA, a scheme conditioned by its low institutionalization and its marked ideological profile caused its development to be contingent on the political cycle and political voluntarism implicit in Venezuela's leadership, which in turn was conditioned by an oil-revenue model that the fall in international oil prices and the collapse of Venezuelan economy during the last few years made unviable (Serbin 2011). In this sense, by applying Nolte's (2006) analytical framework, the development of ideational configurations was essential to compensate for the recent weakness of the oil-dependent diplomacy. Clearly, sustainability and solidarity are not guaranteed when they depend on the revenues originated by oil (or any other 
product). In the absence of economic incentives, greater involvement in the Bolivarian project became difficult.

In short, post-hegemonic proposals lose dynamism and support once the regional power that promoted them weakens. In this vein, a kind of 'hegemonic stability theory' contextualized to South America and the intermediate hegemony of Brazil and Venezuela in recent years seems to be fulfilled around its basic terms: the decline of the leadership of these countries contributes to account for the changes and political reversals in regional governance.

Despite its exploratory nature, this paper offered some insight into the examination of the criteria that a regional power must meet in order to exercise regional leadership, the connection between regional leadership and regionalism, and the dynamics of this connection. Nonetheless, several questions remain to be answered. Further studies need to be undertaken in order to examine the prospect for an inertial evolution of regional institutions that adapt to the absence of regional hegemony.

The rise and fall of ALBA and UNASUR and their connection with the role of Venezuela and Brazil could be a lesson for future attempts to build regional structures. Regionalist efforts need a real leadership that looks beyond national interest and shortterm strategies, yet also that serves as an aspiration for a regionalism forged on solid common institutional foundations. While this ambition may be unachievable in the near future, it is critical to long-term strategic discussions.

\section{Notes}

1 This idea was raised by an anonymous reviewer, to whom I am indebted for the suggestion.

2 We should distinguish it from regionalization, which is spontaneous, and which allows the emergence of certain patterns of cooperation within a given geographical area (Hettne and Söderbaum 2002: 34).

3 Yet it is particularly manifest that the external conditions that enabled the post-hegemonic regionalist turn are no longer present. The favourable commodities economic cycle, that provided the material resources on which more assertive foreign policies were based, has ended. The region has returned to the secular situation of vulnerability vis-à-vis an adverse international context (Sanahuja 2019).

4 In opposition to realist theories, a rich strand of the IR debate on hegemony uses as a base the notion of hegemony advocated by Gramsci (1971) and Cox (1981). The inclusive nature of a Gramsci-inspired approach to leadership was predicated on the notion of consensual hegemony by Burges (2009), applied to Brazilian foreign policy during the Cardoso and Lula presidencies.

5 Some examples of IIRSA/COSIPLAN projects supported by the BNDES include: lines 3 and 4 of the Caracas underground in Venezuela, the hydroelectric plant La Vueltosa in Venezuela, the Santo Francisco Hydroelectric project in Ecuador, the Road 10 in Paraguay, the enlargement of the North gas pipe/TGN in Argentina, the Maldonado waters in Uruguay, and the UTE Transmission lines Punta del Tigre in Uruguay (Pereyra Doval 2014: 163).

6 It should be noted that BNDES and government officials have been prosecuted for alleged corruption within the development bank in recent years.

7 Even though this paper does not engage with MERCOSUR, some consider that the creation of the MERCOSUR Structural Convergence Fund (FOCEM, in Spanish), in order to help gradually eliminate structural asymmetries, was a demonstration that Brazil was progressively assuming the role of paymaster in the bloc (Gomes Saraiva 2012: 94), as the country brought $70 \%$ of the resources in the fund. However, FOCEM limited budget, and the existence of significant unallocated and/or unused amounts, restricted MERCOSUR's potential to exert an impact and attain its objectives (Alvarez 2014). 
'Power-sharing capacity refers to a big power's capacity to share power with its neighbours on a durable basis within common institutions with significant competences' (Pedersen 2002: 689).

9 On 14 December 2004, Venezuela and Cuba signed a bilateral agreement. Later on, a Strategic Plan, agreed on 28 April 2005, became effective. Basically, this Plan conceived 'Cuba's assisting to Venezuela's social missions, mostly in health and education, in exchange for payment facilities for the supply of oil' (Dabène 2009: 210).

10 Accessions to ALBA: Bolivia (2006), Nicaragua (2007), Dominica and Honduras (2008), Antigua and Barbuda, Ecuador, Saint Vincent and the Grenadines (2009), Suriname (2012), Saint Lucia (2013), Saint Kitts and Nevis and Granada (2014). Honduras withdrew from the bloc in 2009, Ecuador in 2018, and Bolivia in 2019.

11 ALBA presented itself as a regionalist scheme without geographical contiguity, 'contrary to the traditional concept of regionalism that requires territorial contiguity among the member countries' (Briceño Ruiz 2014: 162).

12 It is possible to refer to Venezuela as a 'regional middle' (Cardozo de Da Silva 1987, cited in Flemes and Wojczewski 2010: 10) and a 'regional leading power' (Boeckh 2003, cited in Flemes and Wojczewski 2010: $10)$.

13 The agreement was centred on social issues, with Cuba and Venezuela committed to helping Bolivia reduce poverty and educate the poorest sectors of its population (Dabène 2009: 210).

14 Venezuela's oil diplomacy was not a new phenomenon; rather, it had a long trajectory in the country's history. The link between foreign policy, oil and regional projection in the Venezuelan case was highlighted during the launch of the so-called strategic oil cooperation partnerships such as Petroamérica, which included Petrocaribe, Petroandina and Petrosur (Lorenzini and Ceppi 2013).

15 The Chávez administration granted a preferential treatment to the 18 member states, allowing them to only pay $40 \%$ of their imported oil, as opposed to the payment of the rest, over a twenty-five year period with an interest rate of only 1\% (Dabène 2009: 184).

16 In fact, it is difficult not to relativize the post-hegemonic vocation of ALBA as long as one of its countries was part of the DR-CAFTA; in another, the dollar was the official currency and the group leader's most important trading partner was the USA (Briceño Ruiz 2014: 171). Even Ecuador, which joined ALBA in 2009 under the presidency of Rafael Correa, signed with that same government a comprehensive trade agreement with the EU in 2016 (joining Colombia and Peru).

17 The value of the concessional financing terms rose from US\$1,174m in 2006 to US\$4,803m in 2012. Meanwhile, in 2011, Spain spent US\$4,477m in ODA, Italy US\$4,626m and Norway US\$4,756m (DAC1OECD data) (López Canellas and Villani 2014: 196).

18 Much of Bolsonaro's political support comes from the agribusiness, the arms industry, and the religious right - a nexus of power referred to as the Three 'B's': beef, bullets, and Bibles. These groups exert an enormous influence on Brazilian foreign affairs under Bolsonaro's administration.

19 Excluding the decline in production during the 2002-03 strike (Energy Information Administration [USA] 2019).

20 In 2005, Venezuela's daily output was 3.3m barrels per day. By 2016, it was down to $2.4 \mathrm{~m}$ barrels (International Association of Oil \& Gas Producers IOGP 2018). As of May 2018, crude oil production was $1.4 \mathrm{~m}$ barrels per day (Energy Information Administration [USA] 2019).

21 US refiners are among the few customers that still remit cash payments. The remaining crude oil exports are sold domestically at a loss or sent as loan repayments to China and Russia (Energy Information Administration [USA] 2019).

22 Venezuela and El Salvador broke diplomatic relations in November 2019, expelling one another's diplomatic missions from their national territories. 


\section{References}

Alvarez, M V. 2014. 'La Cooperación Sur-Sur en el MERCOSUR. Luces y Sombras del Fondo de Convergencia Estructural (FOCEM).' In Gladys Lechini (ed), La Cooperación Sur-Sur en las políticas exteriores de Argentina y Brasil en el Siglo XXI. Rosario: UNR Editora, pp. 74-85.

2020. 'La declinación del liderazgo y el regionalismo: los casos de Brasil en UNASUR y Venezuela en ALBA.' In Gladys Lechini and Carla Morasso (ed), Auge y ocaso de los emergentes en el siglo XXI. ¿Cambios sistémicos, domésticos o cosméticos? Rosario: UNR Editora, pp. 30-54.

Antonin, A. 2018. ¿¿Dónde está el dinero de Petrocaribe? Las protestas anticorrupción que acorralan al gobierno haitiano.' Nueva Sociedad. At http://nuso.org/articulo/haiti-corrupcion-petrocaribe-venezuela/ [Accessed on 8 December 2019]

Briceño Ruíz, J. 2012. 'La Alianza del Pacífico: la viabilidad de un naciente bloque regional.' In Martha Ardila (ed), El Pacífico latinoamericano y su inserción internacional. Bogotá: Pontificia Universidad Javeriana, pp. 135-158.

2014. 'El ALBA: una discusión de su modelo, sus resultados y sus perspectivas.' In Andrés Serbin, Laneydi Martínez and Haroldo Ramanzini Júnior (eds), Anuario de la Integración Regional de América Latina y el Caribe, № 10. Buenos Aires: CRIES, pp. 151-178.

2018. 'Times of Change in Latin American Regionalism.' Contexto Internacional 40 (3): 573-594.

Burges, S W. 2009. Brazilian Foreign Policy after the Cold War. Gainesville: University Press of Florida.

Caetano, G, C L Burian and C Luján. 2019. 'Liderazgos y regionalismos en las relaciones internacionales latinoamericanas.' Revista CIDOB d'Afers Internacionals 121: 181-207.

Cox, R. 1981. 'Social Forces, States and World Orders: Beyond International Relations Theory' Millennium - Journal of International Studies 10 (2): 126-55.

Dabène, Olivier. 2009. The politics of regional integration in Latin America. Theoretical and Comparative Explorations. Basingstoke: Palgrave Macmillan.

Destradi, S. 2008. 'Empire, Hegemony, and Leadership: Developing a Research Framework for the Study of Regional Powers.' GIGA Working Papers 79. At https://www.files.ethz.ch/isn/57203/wp79. pdf [Accessed on 8 May 2020].

2010. 'Regional powers and their strategies: empire, hegemony, and leadership'. Review of International Studies 36 (4): 903-30.

Energy Information Administration [USA]. 2019. Venezuela. Executive Summary. At https://www. eia.gov/international/analysis/country/VEN [Accessed on 20 March 2020].

Flemes, D and T Wojczewski. 2010. 'Contested leadership in international relations: power politics in South America, South Asia and Sub-Saharan Africa.' GIGA Working Papers 121. At http://repec. giga-hamburg.de/pdf/giga_10_wp121_flemes-wojczewski.pdf [Accessed on 21 May 2020].

Frenkel, A. 2018. 'El mundo según Bolsonaro. La nueva política exterior de Brasil.' Nueva Sociedad. At https://nuso.org/articulo/el-mundo-segun-bolsonaro/ [Accessed on 17 February 2020]

Gilpin, R. 1975. U.S. Power and the Multinational Corporation. New York: Basic Books.

Gomes Saraiva, M. 2010. 'Brazilian foreign policy towards South America during the Lula Administration: caught between South America and MERCOSUR?' Revista Brasileira de Politica Internacional 53 (special issue): 151-68. 
2012. 'Procesos de integración de América del Sur y el papel de Brasil: los casos del MERCOSUR y la UNASUR.' Revista CIDOB d'afers internacionals (97-98): 87-100.

Gramsci, A. 1971. Selections from the Prison Notebooks. New York: International Publisher.

Hettne, B and F Söderbaum. 2002. 'Theorising the rise of regionness.' In S Breslin, C W Hughes, N Phillips and B Rosamond (eds), New Regionalism in the Global Political Economy Theories and Cases. London: Routledge, pp. 33-47.

Ikenberry, J G. 2001. 'American power and the empire of capitalist democracy'. Review of International Studies 27 (5): 191-212.

International Association of Oil \& Gas Producers (IOGP). 2018. Global Energy Brief, Oil \& gas production in Central \& South America: Investment needed to meet rising regional demand. At https:// www.iogp.org/bookstore/product/global-energy-brief-latin-america/ [Accessed on 4 March 2020]

Kennedy, D and B Beaton. 2016. 'Two Steps Forward? Assessing Latin American Regionalism through CELAC', Latin American Policy 7 (1): 52-79.

Keohane, R 1984. After hegemony: Cooperation and discord in the world political economy. Princeton: Princeton University Press.

Kindleberger, C P. 1974. The World in Depression, 1929-1939. Berkeley: University of California Press. Knorr, K. 1975. The Power of Nations: The Political Economy of International Relations. New York: Basic Books, Inc.

Krasner, S D. 1976. 'State Power and the Structure of International Trade.' World Politics 28 (3): 317-47. López Canellas, M F and D Villani. 2014. 'El acuerdo Petrocaribe en el marco de la Cooperación Sur - Sur y su relevancia política y económica.' In A Serbin, L Martínez and H Ramanzini Júnior (eds), Anuario de la Integración Regional de América Latina y el Caribe, No. 10. Buenos Aires: CRIES, pp. 179-206.

Lorenzini, M E and N Ceppi. 2013. 'Bolivia y Venezuela como PRM’s. Un análisis comparativo en torno a la cooperación internacional.' In M Colacrai (ed), La Cooperación Internacional desde la visión de los PRM: discusiones conceptuales, diseños de políticas y prácticas sudamericanas. Rosario: UNR Editora, pp. 189-224.

Ludwig, F J and I B Sposito. 2020. 'Brazil and its regional projection: perspectives on hegemony and regionalism in South America in the post-cold war era.' Revista Conjuntura Austral 11 (54): 176-94. Malamud, A. 2011. 'A Leader Without Followers? The Growing Divergence Between the Regional and Global Performance of Brazilian Foreign Policy.' Latin American Politics and Society 53 (3): 1-24. Mattli, W. 1999. The logic of Regional Integration. Europe and Beyond. Cambridge: Cambridge University Press.

Mourón, F and J Onuki. 2015. ¿¿Brasil es un líder en América del Sur? El papel brasileiro a través del concepto de liderazgo situacional', Estudos Internacionais 3 (1): 9-25.

Nolte, D. 2006. 'Potencias regionales en la política internacional: conceptos y enfoques de análisis' GIGA Working Papers 30. At http://repec.giga-hamburg.de/pdf/giga_06_wp30_nolte.pdf [Accessed on 20 February 2020]

Payne, A. 1994. 'US hegemony and the reconfiguration of the Caribbean.' Review of International Studies 20 (2): 149-68.

Pedersen, T. 2002. 'Cooperative hegemony: Power, Ideas and Institutions in Regional Integration.' Review of International Studies 28 (4): 677-96. 
Pereyra Doval, G. 2014. ‘QQuo vadis, Brasil? ¿Potencia emergente o golpe de suerte?’ Revista del CESLA (17): 151-79.

. 2019. 'Giro a la derecha y política exterior brasileña en tiempos de Bolsonaro.' In M E Lorenzini and N Ceppi (eds), Zooms sudamericanos: agendas, vínculos externos y desafíos en el Siglo XXI. Rosario: UNR Editora, pp. 47-65.

Poggio Teixeira, C G. 2011. 'Brazil and the institutionalization of South America: from hemispheric estrangement to cooperative hegemony.' Revista Brasileira de Política Internacional 54 (2): 189-211. Quiliconi, C and R Salgado Espinoza. 2017. 'Latin American Integration: Regionalism à la Carte in a Multipolar World?', Colombia Internacional (92): 15-41.

Riggirozzi, P. 2012. 'Reconstructing Regionalism: What does Development have to do with it?' In P Riggirozzi and D Tussie (eds), The rise of Post-hegemonic regionalism: the case of Latin America. London: Springer, pp. 17-39.

Riggirozzi, P and D Tussie. 2012. 'The Rise of Post-Hegemonic Regionalism in Latin America.' In $\mathrm{P}$ Riggirozzi and D Tussie (eds), The rise of Post-hegemonic regionalism. The case of Latin America. London: Springer, pp. 1-16.

Sanahuja, J A. 2012. 'Regionalismo post-liberal y multilateralismo en Sudamérica: El caso de UNASUR.' In A Serbin, L Martínez and H Ramanzini Júnior (eds), Anuario de la Integración Regional de América Latina y el Caribe, No. 10. Buenos Aires: CRIES, pp. 19-71.

. 2016. 'Regionalismo e integración en América Latina: de la fractura Atlántico-Pacífico a los retos de una globalización en crisis.' Pensamiento Propio 44 (21): 29-75.

2019. 'La crisis de integración y el regionalismo en América Latina: giro liberal-conservador y contestación normativa.' In Manuela Mesa (ed), Anuario CEIPAZ 2018-2019. Madrid: CEIPAZ, pp. 107-126.

Serbin, A. 2011. 'Regionalismo y soberanía nacional en América Latina: los nuevos desafíos.' In F Rojas Aravena (ed), América Latina y el Caribe: multilateralismo vs. soberanía. La construcción de la Comunidad de Estados Latinoamericanos y Caribeños. Buenos Aires: Teseo/FLACSO, pp. 49-98.

. 2012. 'Déficit democrático y participación ciudadana en el marco del regionalismo post-liberal'. In A Serbin, L Martínez and H Ramanzini Júnior (eds), Anuario de la Integración Regional de América Latina y el Caribe, No. 10. Buenos Aires: CRIES, pp. 73-127.

Telesur [online]. 2018. 'El ALBA al contragolpe' 20 December. At https://www.telesurtv.net/blog/El-ALBA-al-contragolpe-20181219-0036.html [Accessed on 10 November 2019].

United Nations Statistic Division (n.d.). 'UNdata.' At http://www.data.un.org. [Accessed on 5 November 2020].

\section{About the author}

María Victoria Alvarez is an Associate Professor at the Department of Political Science and International Relations of the National University of Rosario (UNR) in Argentina, the Director of the Study Group on the European Union at the UNR and the Academic Coordinator of a Jean Monnet Project (Erasmus+ Programme). She has been a Visiting Scholar at the Universidade Federal do Paraná (Brazil), the Jean Monnet EU Centre of Excellence-University of Pittsburgh (USA) and at the Laboratory for Interdisciplinary 
Evaluation of Public Policies, Sciences Po-Paris (France). Her research areas of interest include European Union politics and institutions, Euroscepticism, EU-Latin America relations, Latin American regionalism, and comparative regionalism. Her latest publications include “Stranger Things": The Future of Latin American Regionalism' (Conjuntura Austral, September 2020).

\title{
Uma Teoria de Estabilidade Hegemônica para o Regionalismo Sul-Americano? Evidências do Caso do Brasil na UNASUL e da Venezuela na ALBA
}

\begin{abstract}
Resumo: Tanto o Brasil quanto a Venezuela estruturaram suas agendas de política externa no início do século 21 a partir da projeção de suas respectivas lideranças em esquemas regionais como UNASUL e ALBA, respectivamente, seguindo uma estratégia hegemônica intermediária. A perda de dinamismo dessas iniciativas pós-hegemônicas problematiza a relação entre a governança regional e o papel das potências regionais. A ALBA é um esquema contingente ao ciclo político e ao voluntarismo político intrínseco à liderança da Venezuela e o bloco perdeu membros e relevância nos últimos anos. Quanto à UNASUL, a maioria de seus Estados membros se retirou do bloco, que atualmente não está operando. Em suma, as propostas pós-hegemônicas perdem dinamismo e respaldo à medida que a liderança que as promoveu enfraquece. Uma certa 'teoria da estabilidade hegemônica' contextualizada para a América do Sul em relação à liderança do Brasil e da Venezuela nos últimos anos parece ser cumprida: o declínio no poder desses países ajuda a explicar as reversões políticas e mudanças na governança regional.
\end{abstract}

Palavras-chave: regionalismo da América do Sul; UNASUR; ALBA; hegemonia intermediária; Brasil; Venezuela.

Received on 18 April 2020, and approved for publication on 6 October 2020. 